\title{
Ex vivo exposure of bone marrow from chronic kidney disease donor rats to pravastatin limits renal damage in recipient rats with chronic kidney disease
}

\author{
Arianne van Koppen ${ }^{1,2}$, Diana A Papazova ${ }^{1}$, Nynke R Oosterhuis ${ }^{1}$, Hendrik Gremmels ${ }^{1}$, Rachel H Giles ${ }^{1}$, \\ Joost O Fledderus', Jaap A Joles ${ }^{1}$ and Marianne C Verhaar ${ }^{1 *}$
}

\begin{abstract}
Introduction: Healthy bone marrow cell (BMC) infusion improves renal function and limits renal injury in a model of chronic kidney disease (CKD) in rats. However, BMCs derived from rats with CKD fail to retain beneficial effects, demonstrating limited therapeutic efficacy. Statins have been reported to improve cellular repair mechanisms.

Methods: We studied whether exposing CKD rat BMCs ex vivo to pravastatin improved their in vivo therapeutic efficacy in CKD and compared this to systemic in vivo treatment. Six weeks after CKD induction, healthy BMCs, healthy pravastatin-pretreated BMCs, CKD BMCs or CKD pravastatin-pretreated BMCs were injected into the renal artery of CKD rats.

Results: At 6 weeks after BMC injection renal injury was reduced in pravastatin-pretreated CKD BMC recipients vs. CKD BMC recipients. Effective renal plasma flow was lower and filtration fraction was higher in CKD BMC recipients compared to all groups whereas there was no difference between pravastatin-pretreated CKD BMC and healthy $B M C$ recipients. Mean arterial pressure was higher in CKD BMC recipients compared to all other groups. In contrast, 6 weeks of systemic in vivo pravastatin treatment had no effect. In vitro results showed improved migration, decreased apoptosis and lower excretion of pro-inflammatory Chemokine (C-X-C Motif) Ligand 5 in pravastatinpretreated CKD BMCs.
\end{abstract}

Conclusions: Short ex vivo exposure of CKD BMC to pravastatin improves CKD BMC function and their subsequent therapeutic efficacy in a CKD setting, whereas systemic statin treatment did not provide renal protection.

\section{Introduction}

The rapidly increasing number of patients with chronic kidney disease (CKD) worldwide urgently calls for new interventions. Bone marrow (BM)-derived stem and progenitor cell-based therapies have been proposed as a promising approach for the treatment of acute kidney disease and CKD. We recently demonstrated that administration of healthy donor bone marrow cells (BMCs) in an established rat model of CKD reduced progression of CKD [1]. However, for clinical application of BMC

\footnotetext{
* Correspondence: m.c.verhaar@umcutrecht.nl

1 Department of Nephrology \& Hypertension, University Medical Center Utrecht, F03.223, Heidelberglaan 100, Utrecht 3584 CX, The Netherlands Full list of author information is available at the end of the article
}

therapy in CKD, the use of autologous BMCs would be preferred; the challenge is that BMCs derived from CKD donors are unable to recapitulate therapeutic efficacy [1]. Therefore, to optimize autologous BMC therapy for treatment of CKD, we aim to counteract the functional impairment of CKD BMCs.

Several investigators have reported strategies to improve function of autologous BM-derived progenitor cell populations. Systemic treatment with lipid-lowering 3-hydroxy-3-methyl-glutaryl Coenzyme A reductase (HMG$\mathrm{CR}$ ) inhibitors (statins) has been shown to augment endothelial progenitor cell (EPC) and mesenchymal stem cell (MSC) number and function in several disease models, including cardiovascular diseases [2-4] and hypertension 
$[5,6]$. In vitro statin incubation has been reported to improve cell differentiation, proliferation, migration, angiogenesis and adhesion and to decrease senescence, apoptosis and inflammation $[7,8]$, possibly by pleiotropic effects such as increased nitric oxide (NO) bioavailability, anti-inflammatory and antioxidant effects $[2,3,8,9]$ and prevention of cellular senescence via regulation of cell cycle proteins [10].

However, few studies have investigated the effect of in vitro or ex vivo statin treatment on cells obtained from diseased cell source [11-16], and to the best of our knowledge this is the first study to report the effects of statin treatment on cells in the context of CKD. We hypothesized that exposing CKD BMCs to pravastatin ex vivo would improve their subsequent in vivo therapeutic efficacy, ameliorating the progression of renal failure in a rat model of established CKD. To this end, we studied long-term effects of intraarterial delivery of vehicle-pretreated or pravastatinpretreated healthy and CKD BMCs on renal hemodynamics and injury. Our data conclude that while systemic in vivo treatment with pravastatin does not influence the course of CKD, a short ex vivo pulse of pravastatin significantly ameliorates progression of CKD in an established rat model.

\section{Methods}

In vitro experiments

BMCs were harvested at 6 weeks after CKD induction from CKD Lewis rats (for characteristics, see Table 1) and were incubated with or without $1 \mathrm{mmol} / \mathrm{l}$ pravastatin in Dulbecco's modified Eagle medium (DMEM) for 2 hours at $37^{\circ} \mathrm{C}$. Directly after incubation, cells were centrifuged and the conditioned medium was stored for further analysis. Cells were washed, resuspended in $1 \mathrm{ml}$ DMEM and used for assessment of in vitro migration and apoptosis. Then $1 \times 10^{6}$ cells were stored in Trizol (Invitrogen, Grand Island, NY, USA) for RNA extraction.

\section{Bone marrow cell characteristics}

Viability and proportions of myeloid and lymphoid cell precursors were studied by flow cytometry.

\section{Migration assay}

Migration of pretreated CKD BMCs was determined using a modified Boyden chamber assay. Then 300,000

Table 1 Donor characteristics and stratification of donor and recipient rats

\begin{tabular}{|c|c|c|c|c|}
\hline In vitro pravastatin treatment & CKD $(n=10)$ & & & \\
\hline SNX (\%) & $66 \pm 2$ & & & \\
\hline Week 5 SBP (mmHg) & $169 \pm 28$ & & & \\
\hline Week 5 urea $(\mathrm{mmol} / \mathrm{l})$ & $11 \pm 2$ & & & \\
\hline Week 5 proteinuria (mg/24 hours) & $18 \pm 28$ & & & \\
\hline \multicolumn{5}{|c|}{ Ex vivo pravastatin treatment experiment } \\
\hline Donor rats & $\begin{array}{l}\text { Healthy + DMEM BMC } \\
(n=2)\end{array}$ & $\begin{array}{l}\text { Healthy + pravastatin BMC } \\
(n=2)\end{array}$ & $\begin{array}{l}\text { CKD + DMEM BMC } \\
(n=4)\end{array}$ & $\begin{array}{l}\text { CKD + pravastatin BMC } \\
(n=5)\end{array}$ \\
\hline SNX (\%) & - & - & $64.0 \pm 6.0$ & $69.0 \pm 5.5$ \\
\hline Week 5 SBP $(\mathrm{mmHg})$ & - & - & $148 \pm 34$ & $152 \pm 8$ \\
\hline Week 5 urea $(\mathrm{mmol} / \mathrm{l})$ & $4.6 \pm 0.01$ & $4.1 \pm 0.9$ & $15.0 \pm 4.4$ & $15.9 \pm 6.9$ \\
\hline Week 5 proteinuria (mg/24 hours) & $1.4 \pm 0.4$ & $1.8 \pm 0.7$ & $24 \pm 8$ & $49 \pm 46$ \\
\hline Recipient rats & $\begin{array}{l}\text { Healthy + DMEM BMC } \\
(n=5)\end{array}$ & $\begin{array}{l}\text { Healthy + pravastatin BMC } \\
(n=5)\end{array}$ & $\begin{array}{l}\text { CKD + DMEM BMC } \\
(n=10)\end{array}$ & $\begin{array}{l}\text { CKD + pravastatin BMC } \\
(n=9)\end{array}$ \\
\hline SNX (\%) & $66.3 \pm 1.6$ & $66.7 \pm 6.4$ & $66.5 \pm 3.5$ & $67.6 \pm 7.1$ \\
\hline Week 5 SBP (mmHg) & $156 \pm 15$ & $155 \pm 16$ & $159 \pm 25$ & $155 \pm 19$ \\
\hline Week 5 urea $(\mathrm{mmol} / \mathrm{l})$ & $10.1 \pm 0.9$ & $10.3 \pm 1.5$ & $12.1 \pm 3.2$ & $10.6 \pm 2.3$ \\
\hline Week 5 proteinuria (mg/24 hours) & $21.6 \pm 5.6$ & $21.9 \pm 6.8$ & $23.7 \pm 17.3$ & $22.7 \pm 8.4$ \\
\hline \multicolumn{5}{|c|}{ Systemic in vivo pravastatin treatment } \\
\hline Recipient rats & CKD + pravastatin $(n=5)$ & CKD $(n=6)$ & & \\
\hline SNX (\%) & $69 \pm 2$ & $66 \pm 3$ & & \\
\hline Week 5 SBP $(\mathrm{mmHg})$ & $158 \pm 19$ & $159 \pm 10$ & & \\
\hline Week 5 urea $(\mathrm{mmol} / \mathrm{l})$ & $12.7 \pm 1.1$ & $12.8 \pm 1.4$ & & \\
\hline Week 5 proteinuria (mg/24 hours) & $14.6 \pm 2.7$ & $16.5 \pm 6.6$ & & \\
\hline
\end{tabular}

At 1 week before BMC or in vivo pravastatin administration (week 5 after SNX), rats were stratified based on plasma urea and SBP. Data presented as mean \pm standard deviation. BMC, bone marrow cell; CKD, chronic kidney disease; DMEM, Dulbecco's modified Eagle medium; SBP, systolic blood pressure; SNX, subtotal nephrectomy. 
living cells were loaded above a $5 \mu \mathrm{m}$ polycarbonate membrane (transwell permeable support system; Corning, Tewksbury, MA, NY, USA) and the wells below contained $200 \mathrm{ng} / \mathrm{ml}$ stromal derived factor 1 alpha (SDF1 $\alpha$ ), a strong BMC attractant [17]; vehicle (no SDF1 $\alpha$ ) was used as negative control. After 180 minutes, transwells were removed horizontally and $1 \mathrm{ml}$ of $2 \mathrm{mmol} / \mathrm{l}$ phosphatebuffered saline-ethylenediamine tetraacetic acid was added to the bottom well and incubated for 15 minutes on ice. Cell suspensions were collected and counted by flow cytometry. The percentage of migrated DMEM-treated BMCs towards $200 \mathrm{ng} / \mathrm{ml} \mathrm{SDF1 \alpha}$ was set at $100 \%$ and compared with the migration of pravastatin-treated cells.

\section{Apoptosis}

Cell suspension $(50 \mu \mathrm{l})$ was used to create a cell smear, air dried, fixed with formalin and stored at $-20^{\circ} \mathrm{C}$. Terminal deoxynucleotidyl transferase dUTP nick end labeling (TUNEL) staining (Apoptag Plus in situ Peroxidase kit; Millipore, Temecula, CA, USA) was performed according to the manufacturer's guidelines. The number of apoptotic cells was determined as the number of TUNEL-positive cells in the images of 20 randomly selected fields ( $\times 200$ magnification).

\section{Quantitative real-time PCR}

We performed quantitative real-time PCR to determine the effects of pretreatment of CKD BMCs with pravastatin on the mRNA expression of endothelial NO synthase, protein kinase $\mathrm{B}$, monocyte chemotactic protein 1 , tumor necrosis factor alpha and vascular endothelial growth factor (ABiPRiSM 790Sequence Detection System; Applied Biosystems, Foster City, CA, USA). The following TaqMan Gene Expression Assays (Applied Biosystems) were used: endothelial NO synthase, Rn02132634_s1; protein kinase B, Rn00583646_m1; monocyte chemotactic protein 1, Rn00580555_m1; tumor necrosis factor alpha, Rn99999017_m1; vascular endothelial growth factor, Rn00582935_m1; $\beta$-actin, Rn00667869_m1; and calnexin, Rn00596877_m1. Reactions were carried out in duplicate. Cycle time values for genes of interest were normalized for mean cycle time values of Calnexin and $\beta$-actin, which we previously determined to be the two most stable housekeeping genes across all groups using the geNorm program [18], and expressed relative to a calibrator (the DMEM group), using the $\Delta \Delta \mathrm{Ct}$ method. Hence, steady-state mRNA levels were expressed as the $n$-fold difference relative to the calibrator.

\section{Cytokine array}

A rat cytokine array (R\&D Systems, Minneapolis, MN, USA) of 27 cytokines was performed according to the manufacturer's instructions on conditioned medium of BMC samples obtained from six CKD rats pretreated in
DMEM with or without $1 \mathrm{mmol} / \mathrm{l}$ pravastatin as reported previously $[1,19]$. Equal amounts of protein were loaded on the blots. Each spot on the blot is represented in duplicate and averages of the two pixel densities were used to calculate the average pixel density with Image J software (Rasband W.S. Image), National Institute of Health, Bethesda, Maryland, USA). Background staining and spot size were analyzed as recommended by the manufacturer. In brief, images were converted to 8-bit inverted tagged image file format files and spots were circled. Per blot, equal spot sizes were analyzed.

\section{Enzyme-linked immunosorbent assay}

An enzyme-linked immunosorbent assay for chemokine (C-X-C motif) ligand (CXCL) 5 (Sigma, St. Louis, MO, USA) was performed according to the manufacturer's instructions on conditioned medium of BMC samples obtained from six CKD rats pretreated in DMEM with or without $1 \mathrm{mmol} / \mathrm{l}$ pravastatin to validate cytokine array results.

\section{In vivo experiments \\ Chronic kidney disease induction}

The study protocol was approved by the Utrecht University Committee of Animal Experiments. CKD was induced in 8-week-old inbred male Lewis rats (recipients) and enhanced green fluorescent protein $(\mathrm{eGFP})^{+}$Lewis rats (donors) by two-stage subtotal nephrectomy as described previously $(t=0)[1,19]$. At week 5 , CKD was confirmed (plasma urea $>9 \mathrm{mmol} / \mathrm{l}$ ).

\section{Experimental design}

\section{Effects of ex vivo pravastatin-pretreated BMCs in established CKD}

At week 5 after CKD induction recipient rats $(n=29)$ were stratified based on plasma urea and systolic blood pressure (Table 1). At 6 weeks after subtotal nephrectomy, BMCs were harvested from the femur and tibia of healthy or $\mathrm{CKD} \mathrm{eGFP}^{+}$donor rats (for donor characteristics, see Table 1) and suspended in DMEM. The cell suspension was filtered (100 $\mu \mathrm{m}$ sieve) and counted (Abbott Cell-Dyn 1800; Abbott Laboratories, Abbott Park, Illinois, USA). BMCs were incubated with or without 1 $\mathrm{mmol} / \mathrm{l}$ pravastatin in DMEM for 2 hours at $5 \%$ carbon dioxide in a humidified incubator at $37^{\circ} \mathrm{C}$. Cells were washed to remove pravastatin and resuspended in $500 \mu \mathrm{l}$ DMEM. Then $50 \times 10^{6}$ ex vivo pretreated BMC cells were injected directly into the remnant kidney via the renal artery as follows: healthy + DMEM BMC recipients $(n=5)$, CKD rats injected with healthy $\mathrm{eGFP}^{+} \mathrm{BMC}$ exposed to DMEM; healthy + pravastatin BMC recipients $(n=5)$, CKD rats injected with healthy $\mathrm{eGFP}^{+} \mathrm{BMC}$ exposed to pravastatin; CKD + DMEM BMC recipients $(n=10)$, CKD rats injected with $\mathrm{CKD} \mathrm{eGFP}^{+} \mathrm{BMC}$ exposed to 
DMEM; and CKD + pravastatin BMC recipients $(n=9)$, CKD rats injected with CKD eGFP ${ }^{+} \mathrm{BMC}$ exposed to pravastatin. Longitudinal measurements were performed at weeks 7, 9 and 11 after subtotal nephrectomy, and at week 12 (6 weeks after BMC injection) terminal kidney function was measured (see Terminal kidney function). Directly thereafter, rats were sacrificed and tissues were collected and either frozen or fixed in $4 \%$ paraformaldehyde for renal morphology measurements.

\section{Effects of systemic in vivo pravastatin treatment in established CKD}

At week 6 after CKD induction, CKD rats were divided into two groups: CKD $(n=6)$, no supplement in drinking water; and CKD + pravastatin $(n=5), 50 \mathrm{mg} / \mathrm{kg} /$ day pravastatin added to drinking water. Longitudinal measurements were performed at weeks 7, 9 and 11, and at week 12 terminal kidney function was measured (see Terminal kidney function). Directly thereafter, rats were sacrificed and tissues were collected and either frozen or fixed in $4 \%$ paraformaldehyde for renal morphology measurements.

\section{Longitudinal chronic kidney disease evaluation}

Rats were weighed weekly, and at regular intervals 24-hour urine and blood samples were collected and the systolic blood pressure was measured by tail cuff sphygmomanometry at weeks 5, 9 and 11. To collect 24-hour urine, rats were placed in metabolism cages without food for 24 hours, but with free access to water with $2 \%$ glucose. For the systemic in vivo pravastatin treatment studies, pravastatin was also supplemented to the drinking water during urine collection. Urine was collected in antibiotic/antimycotic solution (A5955; Sigma) and stored at $-80^{\circ} \mathrm{C}$. Blood samples were collected from the tail vein. Urinary protein levels were measured with Coomassie blue. Sodium and potassium levels were determined by flame photometry. NO metabolites were measured (Cayman Chemical, Ann Arbor, MI, USA). Plasma urea and plasma and urinary creatinine levels were determined by DiaSys Urea CT FS (DiaSys Diagnostic Systems, Holzheim, Germany). Creatinine clearance was calculated by dividing urine creatinine excretion ( $\mu \mathrm{mol} / \mathrm{minute} / 100 \mathrm{~g}$ body weight) by plasma creatinine $(\mu \mathrm{mol} / \mu \mathrm{l})$. Cholesterol and triglycerides were determined by DiaSys Cholesterol FS and DiaSys Triglycerides FS (DiaSys Diagnostic Systems).

\section{Terminal kidney function}

Kidney function was assessed by inulin clearance to determine the glomerular filtration rate (GFR) and by para-amino hippuric acid clearance to determine the effective renal plasma flow (ERPF) as described previously [20]. Briefly, rats were anesthetized with isoflurane and placed on a servo-controlled surgical table to maintain body temperature at $37^{\circ} \mathrm{C}$. A polyethylene-90 catheter was placed in the left jugular vein for infusion of solutions. The left femoral artery was cannulated with polyethylene50 tubing for measurement of mean arterial pressure and blood sampling. A polyethylene-90 catheter was placed in the bladder for urine collection. During surgery, animals received an intravenous infusion of a $150 \mathrm{mmol} / \mathrm{l} \mathrm{NaCl}$ solution containing $6 \%$ bovine serum albumin. Following surgery, the infusion was switched to a $150 \mathrm{mmol} / \mathrm{l} \mathrm{NaCl}$ solution with $1 \%$ bovine serum albumin at the same infusion rate. This infusion was maintained throughout the experiment. The solution also contained inulin and paraamino hippuric acid for clearance measurements. A 60minute equilibration period was observed before the start of the 60-minute clearance measurements. During this clearance, measurement urine was sampled for 15-minute periods and both before and after the clearance measurement blood was sampled. Clearance and fractional excretions were calculated by standard formulas. Renal blood flow was calculated from ERPF and hematocrit.

\section{Renal and cardiac morphology}

Focal glomerulosclerosis and tubular interstitial damage were scored on $3 \mu \mathrm{m}$ periodic acid Schiff-stained paraffinembedded slides $[1,19]$. Glomerular influx of donor BMCs $\left(\mathrm{eGFP}^{+}\right)$and the presence of $\mathrm{T}$ cells $\left(\mathrm{CD}^{+}\right)$, monocytes/ macrophages $\left(\mathrm{ED}-1^{+}\right)$, proliferating cells $\left(\mathrm{Ki} 67^{+}\right)$, apoptotic cells $\left(\mathrm{TUNEL}^{+}\right)$, cells undergoing DNA damage repair $\left(\gamma \mathrm{H} 2 \mathrm{AX}^{+}\right)$and endothelial cells $\left(\mathrm{JG}^{+} 2^{+}\right)$was counted in 50 glomeruli [21]. The tubular number of $\mathrm{T}$ cells $\left(\mathrm{CD}^{+}\right)$, apoptotic cells (TUNEL ${ }^{+}$) and cells undergoing DNA damage repair $\left(\gamma \mathrm{H} 2 \mathrm{AX}^{+}\right)$and influx of donor BMCs $\left(\mathrm{GFP}^{+}\right)$ were determined in 20 tubular fields as described previously $[1,19]$. Cardiac collagen I and collagen III contents were stained with Sirius red, visualized with circular polarized light and digitally analyzed using ImageJ software [22]. The percentage of collagen area was calculated by dividing the Sirius red stained area by the total image area.

\section{Blood and bone marrow characteristics}

Blood and BM were incubated with the cell-permeable DNA binding dye Vybrant DyeCycle ${ }^{\mathrm{Tm}}$ Violet (Invitrogen/ Life, Bleiswijk, the Netherlands) for 30 minutes at $37^{\circ} \mathrm{C}$ to allow separation of nucleated cells from debris. Red blood cells were then lysed by incubation with a $0.8 \%$ ammonium chloride lysis solution and samples were washed with phosphate-buffered saline prior to flow cytometry. During flow cytometry, debris and dead cells were excluded by lack of DyeCycle binding and 7-aminoactinomycin D (Invitrogen) staining, respectively. The remaining cells were divided into major leukocyte subpopulations (that is, lymphocytes, monocytes, granulocytes) on the basis of low-angle forward scatter and orthogonal ('side') scatter properties. Gates for the fluorescent stains and eGFP were set on fluorescence-minus-one controls, and gates for 
Table 2 Bone marrow cell characteristics measured by fluorescence-activated cell sorting analysis

\begin{tabular}{lll}
\hline In vitro pravastatin treated cells & \\
Bone marrow samples & DMEM $(n=10)$ & Pravastatin $(n=10)$ \\
Granulocytes & $31.5 \pm 2.6$ & $30.8 \pm 2.2$ \\
Lymphocytes & $37.4 \pm 2.6$ & $38.6 \pm 2.5$ \\
Monocytes & $10.3 \pm 1.9$ & $10.9 \pm 1.9$ \\
Stromal cells & $7.9 \pm 3.6$ & $7.5 \pm 3.5$ \\
Viability & $96.6 \pm 3.4$ & $97.0 \pm 2.5$ \\
Systemic in vivo pravastatin treatment recipients \\
Bone marrow samples & CKD $(n=6)$ & CKD + pravastatin $(n=5)$ \\
Granulocytes & $23.6 \pm 1.5$ & $23.8 \pm 1.3$ \\
Lymphocytes & $31.76 \pm 2.8$ & $31.8 \pm 2.5$ \\
Monocytes & $21.3 \pm 0.77$ & $16.9 \pm 1.3^{*}$ \\
Stromal cells & $6.04 \pm 0.4$ & $7.76 \pm 0.50^{*}$ \\
Viability & $96.8 \pm 0.4$ & $97.7 \pm 0.01^{*}$
\end{tabular}

Data presented as mean \pm standard deviation. CKD, chronic kidney disease; DMEM, Dulbecco's modified Eagle medium. ${ }^{*} P<0.05$ versus CKD.

leukocyte subpopulations were set for each population center on the contour plot. A volumetric estimate of leukocyte subpopulation proportions was furthermore obtained using an automated hematology analyzer (Abbott Cell-Dyn 1800).

\section{Quantitative real-time PCR}

To ascertain that the dose of pravastatin was sufficient, the production of HMGCR was evaluated. cDNA was isolated from frozen liver tissue and expression of HMGCR (Rn00565598_m1) was determined using quantitative real-time RT-PCR as described for the in vitro experiments.

\section{Statistical analyses}

Data are presented as mean \pm standard deviation and analyzed by analysis of variance (one-way analysis of variance with a Student-Newman-Keuls post test, twoway analysis of variance with a Bonferroni post test, and Student's $t$ test) with Graphpad Prism software (GraphPad, La Jolla, CA, USA). $P<0.05$ was considered significant.

\section{Results}

\section{In vitro experiments}

In vitro pravastatin pre-treatment of $B M C$ s improves $B M C$ function

Pravastastin treatment of CKD BMC did not induce differences in myeloid and lymphoid precursor cell composition (Table 2). CKD + pravastatin BMCs showed increased migration towards $200 \mathrm{ng} / \mathrm{ml} \mathrm{SDF} 1 \alpha$ as compared with CKD + DMEM BMCs in eight out of 10 rats $(P=0.014$; Figure 1). Fewer apoptotic cells were found in CKD + pravastatin $\mathrm{BMCs}$ versus CKD + DMEM BMCs in eight out of 10 rats $(P=0.16$; Figure 2$)$. Pravastatin treatment of CKD BMCs did not alter mRNA expression of tumor necrosis factor alpha, endothelial NO synthase, protein kinase $\mathrm{B}$, monocyte chemotactic protein 1 or vascular endothelial growth factor genes (Table 3). Of the $27 \mathrm{cy}$ tokines tested on a cytokine array, we could only detect expression of four cytokines. Pravastatin treatment of CKD BMCs decreased the secretion of proinflammatory CXCL5 and increased CXCL7, whereas secretion of Lselectin and soluble intracellular adhesion molecule was not different between DMEM-treated and pravastatintreated CKD BMCs (Figure 3). Decreased CXCL5 secretion by CKD + pravastatin BMCs compared with DMEM-treated CKD BMCs was confirmed by enzymelinked immunosorbent assay (60 \pm 12 vs. $98 \pm 31 \mathrm{pg} / \mathrm{ml}$; $P=0.0045)$.

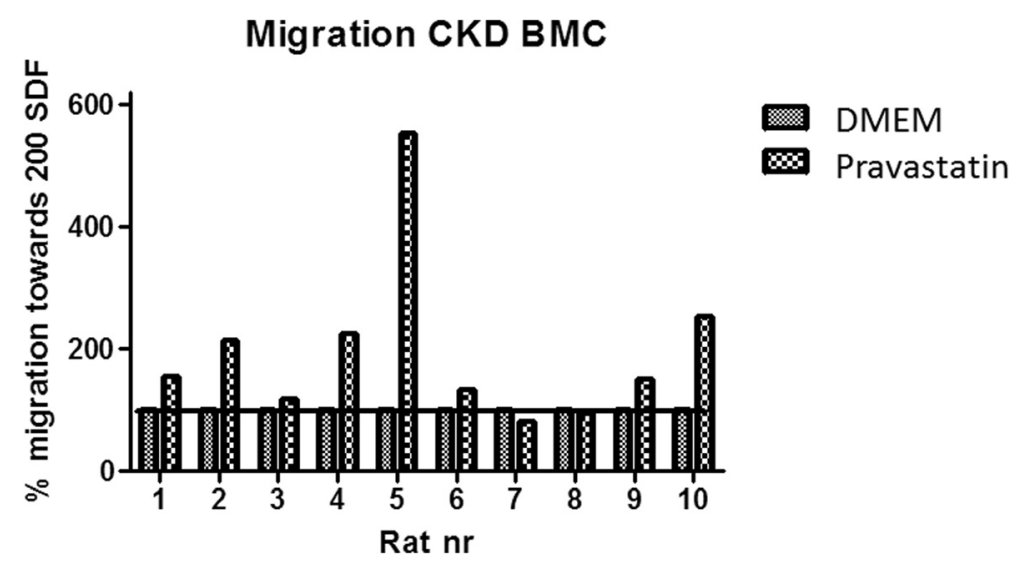

Figure 1 Effect of in vitro pravastatin treatment on migration capacity of chronic kidney disease bone marrow cells. Dulbecco's modified Eagle medium (DMEM; $n=10)$; pravastatin $(n=10)$. BMC, bone marrow cell; CKD, chronic kidney disease; SDF, stromal derived factor. 


\section{TUNEL staining}

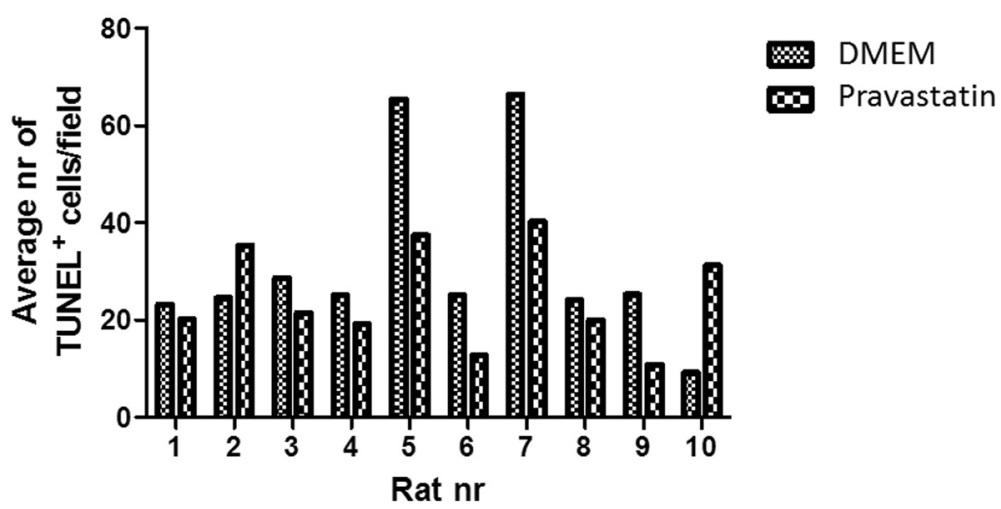

Figure 2 Effect of in vitro pravastatin treatment on apoptosis in chronic kidney disease bone marrow cells. Dulbecco's modified Eagle medium (DMEM; $n=10)$; pravastatin $(n=10)$. TUNEL, Terminal deoxynucleotidyl transferase dUTP nick end labeling.

\section{In vivo experiments}

Ex vivo pravastatin pre-treatment of CKD BMC improves in vivo therapeutic efficacy

As compared with healthy + DMEM BMC recipients, CKD + DMEM BMC recipients had a 38\% lower GFR and $45 \%$ lower ERPF at week 12. However, in CKD + pravastatin BMC recipients the GFR and ERPF were not significantly different compared with healthy + DMEM $\mathrm{BMC}$ recipients (Table 4). Terminal mean arterial pressure was $20 \mathrm{mmHg}$ lower in $\mathrm{CKD}+$ pravastatin $\mathrm{BMC}$ recipients compared with CKD + DMEM BMC recipients and not different from either healthy + DMEM BMC recipients or healthy + pravastatin BMC recipients (Table 4). Hematocrit was lower in CKD + DMEM BMC recipients versus healthy + DMEM BMC recipients, but higher in $\mathrm{CKD}+$ pravastatin BMC recipients versus CKD BMC recipients (Table 4). The filtration fraction was higher in CKD BMC recipients versus healthy BMC recipients, whereas in $\mathrm{CKD}+$ pravastatin $\mathrm{BMC}$ recipients the filtration fraction was not significantly different versus healthy + DMEM BMC recipients (Table 4). Terminal body, kidney and heart weights did not differ (Table 4).

Table 3 Gene expression in chronic kidney disease bone marrow cells not changed after in vitro treatment with pravastatin

\begin{tabular}{llll}
\hline & DMEM $(\boldsymbol{n}=\mathbf{1 0})$ & Pravastatin $(\boldsymbol{n}=\mathbf{1 0})$ & $\boldsymbol{P}$ value \\
\hline TNFa & $1.000 \pm 1.290$ & $0.868 \pm 0.969$ & 0.7504 \\
eNOS & $1.000 \pm 4.609$ & $2.161 \pm 2.874$ & 0.5422 \\
PKB & $1.000 \pm 0.889$ & $0.905 \pm 0.5512$ & 0.6906 \\
MCP-1 & $1.000 \pm 1.254$ & $1.191 \pm 0.6933$ & 0.6101 \\
VEGF & $1.000 \pm 0.566$ & $0.687 \pm 0.464$ & 0.0807
\end{tabular}

Data presented as mean \pm standard deviation, expressed as fold change. DMEM, Dulbecco's modified Eagle medium; eNOS, endothelial nitric oxide synthase; MCP-1, monocyte chemotactic protein 1; PKB, protein kinase B; TNFa, tumor necrosis factor alpha; VEGF, vascular endothelial growth factor.
At week 11, plasma urea was higher in CKD + DMEM $\mathrm{BMC}$ recipients compared with healthy + DMEM BMC recipients $(16.1 \pm 7.9$ vs. $10.7 \pm 1.7 \mathrm{mmol} / \mathrm{l}, P<0.05)$, whereas CKD + pravastatin BMC recipients (12.9 \pm 3.2 $\mathrm{mmol} / \mathrm{l})$ were not significantly different from healthy + DMEM BMC recipients $(10.7 \pm 1.7 \mathrm{mmol} / \mathrm{l})$ (Figure $4 \mathrm{~A})$. Diuresis, proteinuria, creatinine clearance, and excretion of NO metabolites were not significantly different between groups, but from weeks 7 to 11 natriuresis was higher in CKD + pravastatin BMC recipients versus CKD + DMEM $\mathrm{BMC}$ recipients $(1,680 \pm 473$ vs. $1,176 \pm 233 ; P<0.05$; Figure 4B,C,D,E,F).

In all CKD groups, only $10 \%$ of glomeruli were completely normal, confirming severe kidney injury. The number of totally sclerotic glomeruli was higher in CKD + DMEM

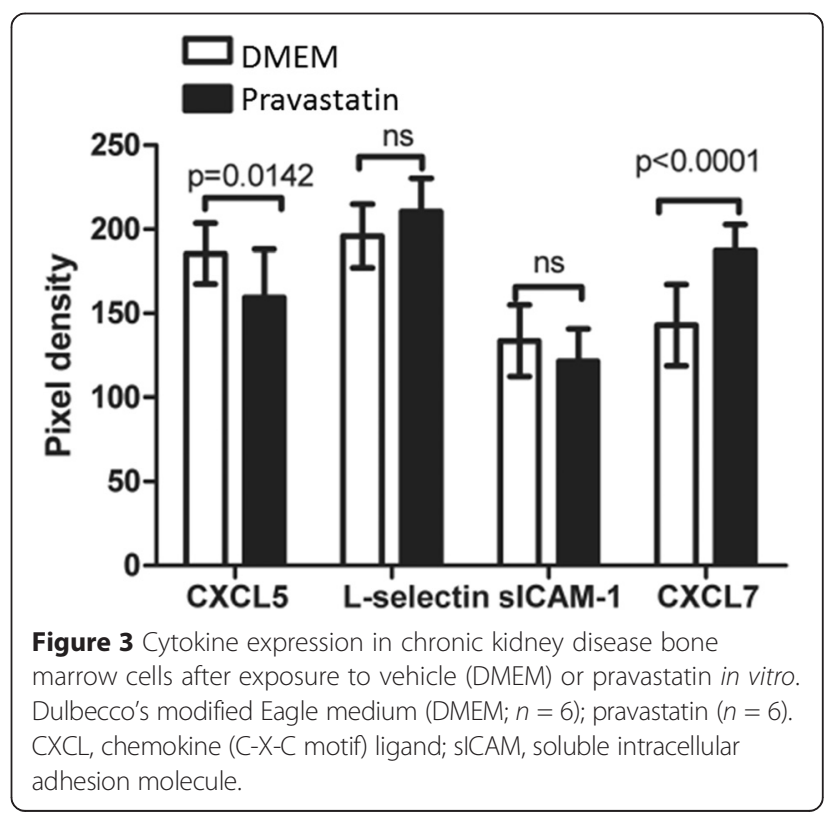


Table 4 Terminal measurements of bone marrow cell recipients with post hoc $P$ values

\begin{tabular}{|c|c|c|c|c|c|c|}
\hline Week 12 & $\begin{array}{l}\text { Healthy + DMEM } \\
\text { BMC recipients } \\
(n=5)\end{array}$ & $\begin{array}{l}\text { Healthy + pravastatin } \\
\text { BMC recipients } \\
(n=5)\end{array}$ & $\begin{array}{l}\text { CKD + DMEM } \\
\text { BMC recipients } \\
(n=10)\end{array}$ & $\begin{array}{l}\text { CKD + pravastatin } \\
\text { BMC recipients } \\
(n=9)\end{array}$ & $\begin{array}{l}\text { CKD + DMEM } \\
\text { BMC vs. healthy + } \\
\text { DMEM BMC }\end{array}$ & $\begin{array}{l}\text { CKD + DMEM } \\
\text { BMC vs. CKD + } \\
\text { pravastatin BMC }\end{array}$ \\
\hline Body weight (g) & $376 \pm 23$ & $379 \pm 26$ & $359 \pm 38$ & $373 \pm 22$ & ns & ns \\
\hline $\begin{array}{l}\text { Heart weight } \\
\text { (g/100 g BW) }\end{array}$ & $0.44 \pm 0.07$ & $0.44 \pm 0.03$ & $0.47 \pm 0.08$ & $0.44 \pm 0.05$ & ns & ns \\
\hline $\begin{array}{l}\text { Kidney weight } \\
\text { (g/100 g BW) }\end{array}$ & $0.59 \pm 0.07$ & $0.56 \pm 0.05$ & $0.53 \pm 0.06$ & $0.55 \pm 0.04$ & 0.063 & ns \\
\hline MAP $(\mathrm{mmHg})$ & $149 \pm 28$ & $146 \pm 35$ & $173 \pm 21$ & $153 \pm 21$ & 0.095 & 0.091 \\
\hline GFR ( $\mu \mathrm{l} /$ minute/100 g) & $371 \pm 68$ & $352 \pm 119$ & $237 \pm 159$ & $261 \pm 149$ & 0.057 & ns \\
\hline ERPF ( $\mu / /$ minute/100 g) & $1538 \pm 224$ & $1388 \pm 502$ & $844 \pm 626^{*}$ & $1157 \pm 359$ & $<0.05$ & ns \\
\hline Hematocrit & $0.45 \pm 0.01$ & $0.44 \pm 0.01$ & $0.42 \pm 0.03^{*}$ & $0.46 \pm 0.02^{\dagger}$ & $<0.05$ & $<0.05$ \\
\hline $\mathrm{FF}(\%)$ & $24.1 \pm 2.4$ & $26.2 \pm 4.7$ & $29.9 \pm 4.5^{*}$ & $26.4 \pm 3.7$ & $<0.05$ & 0.071 \\
\hline
\end{tabular}

Data presented as mean \pm standard deviation. BMC, bone marrow cell; BW, body weight; CKD, chronic kidney disease; DMEM, Dulbecco's modified Eagle medium; ERPF, effective renal plasma flow; FF, filtration fraction; GFR, glomerular filtration rate; MAP, mean arterial pressure. ${ }^{*} P<0.05$ compared with healthy $B M C$ recipients, ${ }^{\dagger} P<0.05$ compared with CKD BMC recipients. Trends $(P<0.1)$ are only indicated with the exact $P$ value.

BMC recipients versus healthy + DMEM BMC recipients $(P<0.05)$. Comparing the number of partly and totally sclerotic glomeruli between CKD + DMEM BMC recipients and $\mathrm{CKD}+$ pravastatin $\mathrm{BMC}$ recipients revealed a favorable shift to better preserved glomeruli in CKD + pravastatin BMC recipients $(P<0.05$; Figure $5 \mathrm{~A})$. Tubular interstitial inflammation, tubular atrophy and interstitial fibrosis were all lower in CKD + pravastatin $\mathrm{BMC}$ recipients versus CKD + DMEM BMC recipients (Figure 5B). The number of glomerular inflammatory cells $\left(\mathrm{ED}^{+}\right.$and $\left.\mathrm{CD}^{+}\right)$tended to be higher in CKD + DMEM BMC recipients compared with all other groups. Tubular $\mathrm{CD}^{+}$influx was most abundant in CKD + DMEM BMC recipients (Table 5). Cardiac fibrosis tended to be more abundant in CKD + DMEM $\mathrm{BMC}$ recipients compared with healthy $\mathrm{BMC}+\mathrm{DMEM}$ recipients, as reported previously [23]. In CKD + pravastatin $\mathrm{BMC}$ recipients, cardiac fibrosis tended to be reduced compared with CKD + DMEM BMC recipients $(15.3 \pm 7.6$ vs. $20.5 \pm 4.7 \% ; P=0.085)$. Healthy + pravastatin BMCs did not influence cardiac fibrosis (healthy + DMEM BMC recipients: $16.7 \pm 6.5$ vs. healthy + pravastatin BMC recipients: $16.8 \pm 6.7 \%$ ).

The number of proliferating glomerular cells $\left(\mathrm{Ki} 67^{+}\right)$, endothelial cells $\left(\mathrm{JG}^{+} 2^{+}\right.$), and apoptotic cells $\left(\mathrm{TUNEL}^{+}\right)$ were not significantly different between groups (Table 5). No difference was found in the number of tubular apoptotic $\left(\mathrm{TUNEL}^{+}\right.$) cells, cells expressing DNA damage repair marker $\gamma \mathrm{H}_{2} \mathrm{AX}^{+}$(Table 5), or the number of eGFP ${ }^{+}$ cells. As shown previously, $\mathrm{eGFP}^{+}$cells were detected in the remnant kidney and heart but only in low numbers. No integration of these cells was observed and most were attached to the endothelial lining of small vessels [1]. No differences were observed in blood counts (Table 6).
Systemic in vivo treatment of CKD rats with pravastatin does not reduce CKD progression

CKD rats developed hypertension, mild uremia, anemia and proteinuria (Figure 6). Systemic 6-week in vivo pravastatin treatment did not influence the body weight, GFR, ERPF, filtration fraction or hematocrit (Table 7). Furthermore, no differences in blood counts (Table 6), focal glomerulosclerosis and tubulo-interstitial damage (Table 8$)$, cardiac fibrosis $(3.54 \pm 2.20$ vs. $4.79 \pm 2.71 \%)$ or NO metabolite excretion (Figure 6) were observed between CKD and CKD + pravastatin rats. Cholesterol did not differ between CKD + pravastatin-treated rats and CKD rats; however, triglycerides were significantly lower in CKD + pravastatin-treated rats (Table 7). Systemic pravastatin decreased the number of monocytes and increased the stromal cell population in the BM (Table 2) and increased hepatic HMGCR mRNA expression (Table 7).

\section{Discussion}

The present study demonstrates for the first time that BMC dysfunction in CKD can be reversed by short-term (2 hours) pretreatment with pravastatin outside the CKD environment and that this effect persists when the cells are returned to the $\mathrm{CKD}$ environment, providing augmented therapeutic efficacy in vivo.

Our recent studies have shown that a single injection of healthy BMCs in rats with established CKD slowed progression of the disease, probably via paracrine actions. Less disease progression was characterized by increased glomerular capillary density and less sclerosis. Injection of BMCs derived from CKD rats was less effective [1], suggesting that CKD induces alterations in (paracrine) functions of $\mathrm{BMC}$ which reduce endothelial regenerative capacity and efficacy of CKD BMC therapy 


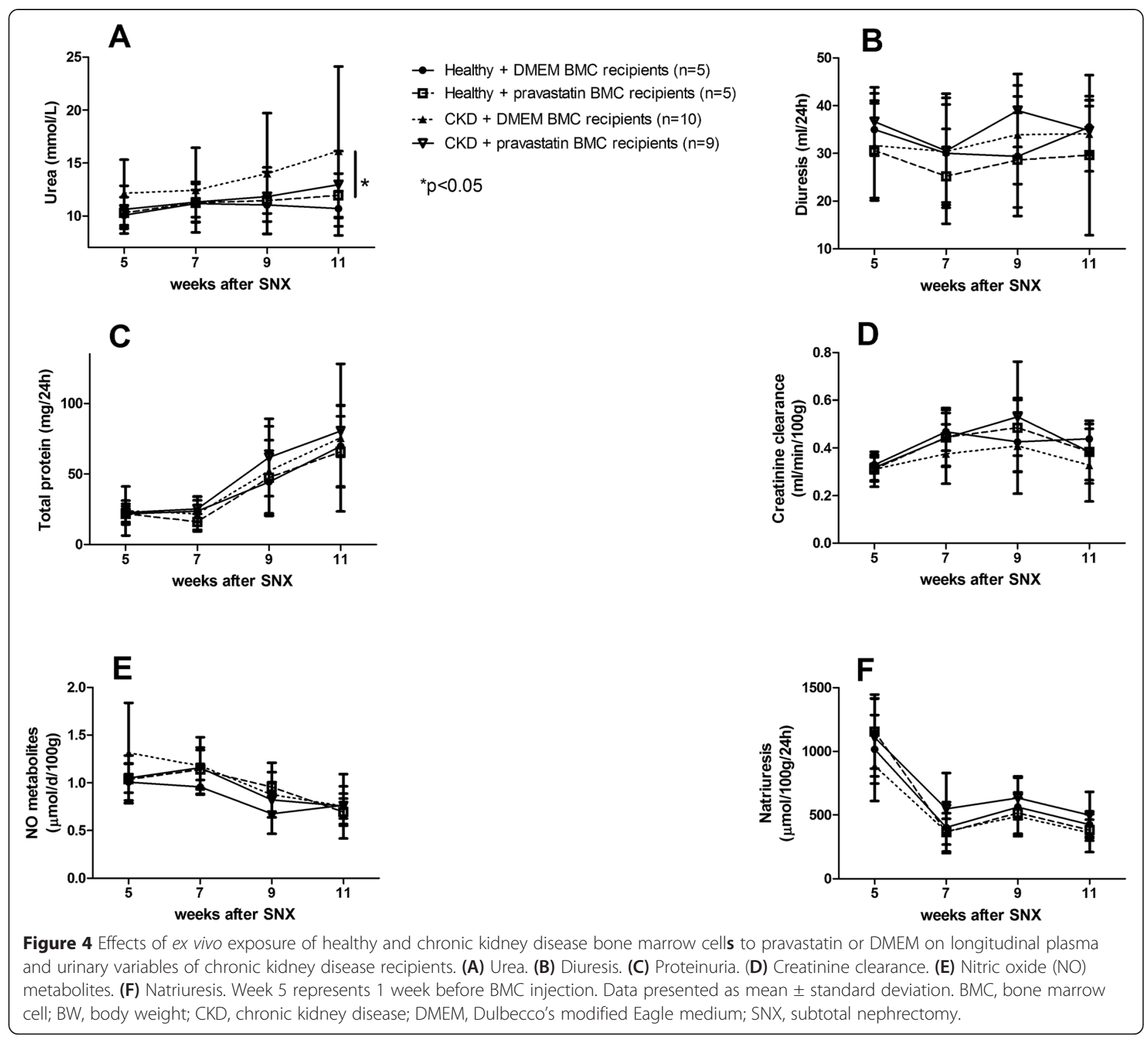

in rats. Previously, statins have been reported to exert beneficial effects on endothelial as well as on BMderived EPC and MSC function both after in vitro incubation and after systemic in vivo treatment [5,7-9]. Here we show that short-term ex vivo pretreatment with pravastatin reverses paracrine dysfunction in BMCs obtained from rats with established CKD, resulting in preserved renal morphology in recipient rats with CKD.

The role of transdifferentiation and incorporation of BMCs in enhancing tissue regeneration has been questioned. BMCs appear to have a supportive function, secreting growth factors and cytokines, thereby stimulating resident cells to engage in regeneration [24]. Using a cytokine array we showed that short-term pravastatin pretreatment influences paracrine factor secretion by BMCs. CKD + pravastatin BMCs significantly decreased expression of the proinflammatory chemokine CXCL5, which was shown to be involved in the recruitment and activation of polymorphonuclear neutrophils and in stimulation of local production of cytokines that have proapoptotic effects [25]. Our findings are in accordance with previous reports that atorvastatin dose-dependently inhibits basal CXCL5 production in human umbilical vein endothelial cells [26] and that simvastatin inhibited CXCL5 release from peripheral blood mononuclear cells [27]. In our experiments, renal influx of inflammatory cells was lowered in CKD + pravastatin BMC recipients versus CKD + DMEM BMC recipients. In glomeruli, there was a trend towards more ED- $1^{+}$macrophages and $\mathrm{CD}^{+} \mathrm{T}$ cells in CKD + DMEM $\mathrm{BMC}$ recipients and the influx in CKD + pravastatin $\mathrm{BMC}$ recipients was lower and comparable with both healthy + DMEM BMC recipients and healthy + pravastatin BMC 

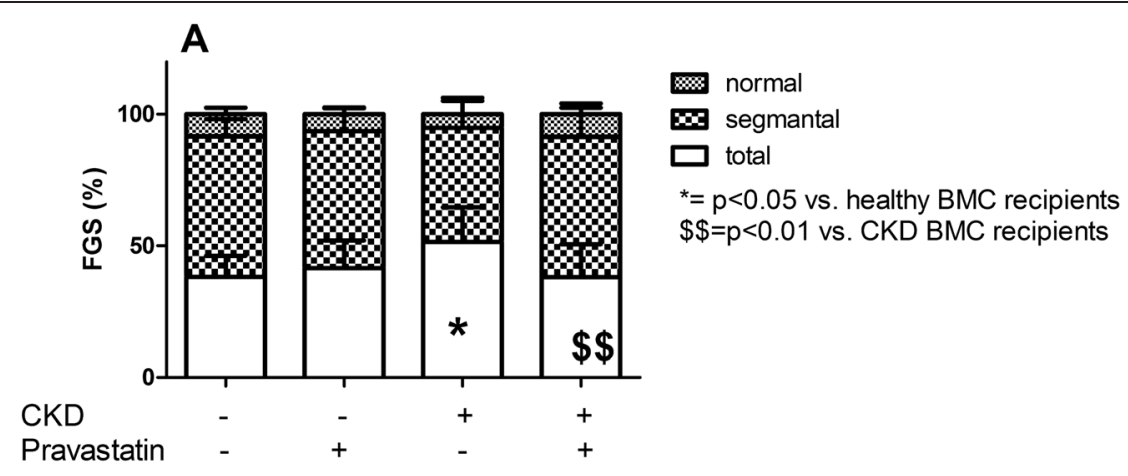

B

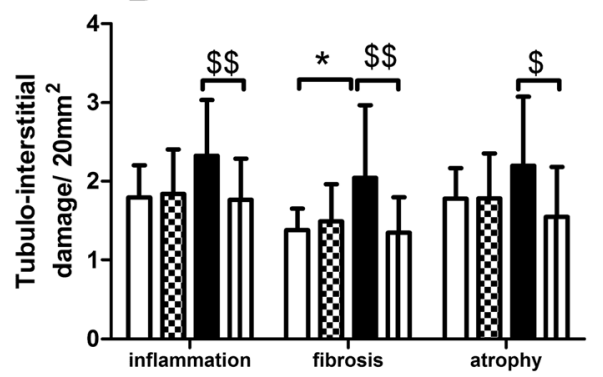

$\square$ Healthy +DMEM BMC recipients $(n=5)$

Healthy + pravastatin $B M C$ recipient $(n=5)$

CKD + DMEM BMC recipients $(n=10)$

س $\mathrm{m} C K D+$ pravastatin BMC recipients $(n=9)$

$*=p<0.05$ vs. Healthy BMC recipients

$\$=p<0.05$ vs. CKD +DMEM BMC recipients

$\$ \$=p<0.01$ vs CKD +DMEM BMC recipients

Figure 5 Effects of ex vivo exposure of healthy and chronic kidney disease bone marrow cells to pravastatin on renal morphology in chronic kidney disease recipients. (A) Focal glomerulosclerosis. (B) Tubulo-interstitial damage. CKD rats received healthy + DMEM BMCs $(n=5)$, healthy + pravastatin BMCs $(n=5)$, CKD + DMEM BMCs $(n=10)$ or CKD + pravastatin BMCs $(n=9) .{ }^{*} P<0.1$ versus healthy BMC recipients, $\$ P<0.1$ and $\$ P<0.05$ versus CKD + DMEM BMC recipients. BMC, bone marrow cell; CKD, chronic kidney disease; DMEM, Dulbecco's modified Eagle medium; FGS, focal glomerulosclerosis.

Table 5 Glomerular and tubular histological characteristics after ex vivo pravastatin pre-treatment

\begin{tabular}{|c|c|c|c|c|}
\hline & $\begin{array}{l}\text { Healthy + } \\
\text { DMEM BMC } \\
\text { recipients } \\
(n=5)\end{array}$ & $\begin{array}{l}\text { Healthy + } \\
\text { pravastatin } \\
\text { BMC recipients } \\
(n=5)\end{array}$ & $\begin{array}{l}\text { CKD + } \\
\text { DMEM BMC } \\
\text { recipients } \\
(n=10)\end{array}$ & $\begin{array}{l}\text { CKD + } \\
\text { pravastatin } \\
\text { BMC recipients } \\
(n=9)\end{array}$ \\
\hline \multicolumn{5}{|c|}{ Glomerular } \\
\hline CD3 & $0.68 \pm 0.34$ & $0.72 \pm 0.33$ & $0.76 \pm 0.19$ & $0.67 \pm 0.27$ \\
\hline ED-1 & $7.4 \pm 1.0$ & $5.0 \pm 2.9$ & $10.5 \pm 5.5$ & $7.9 \pm 1.9$ \\
\hline Ki67 & $8.0 \pm 0.76$ & $6.4 \pm 1.7$ & $7.8 \pm 1.8$ & $7.8 \pm 2.3$ \\
\hline TUNEL & $2.6 \pm 1.3$ & $2.1 \pm 1.3$ & $7.0 \pm 4.6$ & $4.4 \pm 3.7$ \\
\hline$\gamma H 2 A X$ & $1.5 \pm 1.6$ & $0.6 \pm 0.4$ & $1.2 \pm 0.8$ & $1.4 \pm 0.8$ \\
\hline $\mathrm{GFP}^{+}$ & $7.0 \pm 6.6$ & $2.5 \pm 0.7$ & $2.3 \pm 1.9$ & $5.2 \pm 2.9$ \\
\hline JG12 & $42.5 \pm 10$ & $44.4 \pm 9.9$ & $42.8 \pm 12.5$ & $48.1 \pm 9.0$ \\
\hline \multicolumn{5}{|l|}{ Tubular } \\
\hline CD3 & $81 \pm 11$ & $96 \pm 45$ & $122 \pm 59$ & $98 \pm 27$ \\
\hline TUNEL & $35 \pm 24$ & $65 \pm 59$ & $147 \pm 116$ & $95 \pm 79$ \\
\hline$y H 2 A X$ & $5.0 \pm 1.6$ & $4.3 \pm 2.0$ & $6.1 \pm 2.8$ & $5.3 \pm 1.5$ \\
\hline $\mathrm{GFP}^{+}$ & $83 \pm 82$ & $31 \pm 24$ & $23 \pm 20$ & $50 \pm 38$ \\
\hline
\end{tabular}

Data presented as mean \pm standard deviation per 50 glomeruli or 20 tubular fields. BMC, bone marrow cell; CKD, chronic kidney disease; DMEM, Dulbecco's modified Eagle medium; GFP, green fluorescent protein; TUNEL, terminal deoxynucleotidyl transferase dUTP nick end labeling. recipients, suggesting an in vivo anti-inflammatory effect of in vitro pravastatin-pretreated BMCs. Increased paracrine function can explain why we did not observe an increase in the number of $\mathrm{eGFP}^{+}$cells in the remnant kidney. Our observations that few $\mathrm{eGFP}^{+} \mathrm{BMCs}$ were found in kidney sections of all recipients, and that those found were in close proximity to the microvasculature but did not differentiate into endothelial cells, are consistent with paracrine actions of BMCs reported by others [28,29].

Impaired BMC function in CKD rats is consistent with clinical studies reporting impaired function of BMderived EPCs obtained from CKD patients [30,31]. We showed previously that culturing healthy BM mononuclear cells in uremic serum caused reduced outgrowth of EPCs, suggesting that uremic serum contains either impairing toxins or lacks essential stimulants to support EPC function [31]. Indeed, better in vivo removal of uremic toxins in CKD patients has been shown to improve EPC function [32,33]. However, culturing of CKD $\mathrm{BMCs}$ in nonuremic conditions in vitro could not reverse the impairment in outgrowth towards EPCs or EPC function [31,34]. In our study, 2 hours of incubation in DMEM outside a CKD environment did not reverse BMC dysfunction. Importantly, our experiments show that 2 hours of incubation with pravastatin improved rat CKD BMC 
Table 6 Blood cell counts

\begin{tabular}{|c|c|c|c|c|}
\hline \multicolumn{5}{|c|}{ Ex vivo pravastatin pretreatment experiment recipients } \\
\hline $\begin{array}{l}\text { Blood } \\
\text { samples }\end{array}$ & $\begin{array}{l}\text { Healthy + DMEM BMC } \\
\text { recipients }(n=5)\end{array}$ & $\begin{array}{l}\text { Healthy + pravastatin BMC } \\
\text { recipients }(n=5)\end{array}$ & $\begin{array}{l}\text { CKD + DMEM BMC } \\
\text { recipients }(n=10)\end{array}$ & $\begin{array}{l}\text { CKD + pravastatin BMC } \\
\text { recipients }(n=9)\end{array}$ \\
\hline $\begin{array}{l}\text { White blood } \\
\text { cells }\end{array}$ & $5.86 \pm 1.20$ & $5.52 \pm 0.93$ & $4.63 \pm 1.05$ & $5.42 \pm 1.18$ \\
\hline Lymphocytes & $3.30 \pm 1.35$ & $2.54 \pm 0.29$ & $2.60 \pm 0.86$ & $2.94 \pm 0.51$ \\
\hline Midpopulation & $1.58 \pm 0.29$ & $1.56 \pm 0.31$ & $1.18 \pm 0.28$ & $1.59 \pm 0.45$ \\
\hline Granulocytes & $0.98 \pm 0.45$ & $1.38 \pm 0.53$ & $0.84 \pm 0.35$ & $1.08 \pm 0.52$ \\
\hline $\begin{array}{l}\text { Red blood } \\
\text { cells }\end{array}$ & $6.66 \pm 0.40$ & $6.59 \pm 0.36$ & $6.24 \pm 0.59$ & $6.63 \pm 0.23$ \\
\hline Hemoglobin & $8.06 \pm 0.47$ & $7.90 \pm 0.42$ & $7.63 \pm 0.72$ & $7.86 \pm 0.29$ \\
\hline Hematocrit & $0.33 \pm 0.05$ & $0.33 \pm 0.019$ & $0.31 \pm 0.029$ & $0.33 \pm 0.010$ \\
\hline Mcv & $49.08 \pm 0.83$ & $50.08 \pm 1.08$ & $50.10 \pm 2.09$ & $49.35 \pm 0.78$ \\
\hline Mchc & $24.38 \pm 0.22$ & $23.94 \pm 0.38$ & $24.18 \pm 0.43$ & $24.08 \pm 0.36$ \\
\hline Rdw & $15.44 \pm 0.43$ & $15.22 \pm 0.29$ & $15.63 \pm 1.125$ & $15.151 \pm 0.818$ \\
\hline Platelets & $736 \pm 68$ & $697 \pm 49$ & $634 \pm 99$ & $699 \pm 55$ \\
\hline \multicolumn{5}{|c|}{ Systemic in vivo pravastatin treatment } \\
\hline $\begin{array}{l}\text { Blood } \\
\text { samples }\end{array}$ & CKD $(n=6)$ & CKD + pravastatin $(n=5)$ & & \\
\hline $\begin{array}{l}\text { White blood } \\
\text { cells }\end{array}$ & $4.81 \pm 0.89$ & $4.50 \pm 1.16$ & & \\
\hline Lymphocytes & $2.87 \pm 0.59$ & $2.90 \pm 0.97$ & & \\
\hline Midpopulation & $1.27 \pm 0.39$ & $0.90 \pm 0.19$ & & \\
\hline Granulocytes & $0.65 \pm 0.16$ & $0.68 \pm 0.13$ & & \\
\hline $\begin{array}{l}\text { Red blood } \\
\text { cells }\end{array}$ & $6.38 \pm 0.22$ & $6.25 \pm 0.15$ & & \\
\hline Hemoglobin & $7.58 \pm 0.32$ & $7.52 \pm 0.18$ & & \\
\hline Hematocrit & $0.32 \pm 0.01$ & $0.31 \pm 0.01$ & & \\
\hline Mcv & $49.37 \pm 0.79$ & $49.96 \pm 0.32$ & & \\
\hline Mchc & $24.05 \pm 0.25$ & $24.14 \pm 0.23$ & & \\
\hline $\mathrm{Rdw}$ & $15.13 \pm 0.63$ & $15.14 \pm 0.68$ & & \\
\hline Platelets & $681 \pm 42$ & $666 \pm 41$ & & \\
\hline
\end{tabular}

Data presented as mean \pm standard deviation. BMC, bone marrow cell; CKD, chronic kidney disease; DMEM, Dulbecco's modified Eagle medium. Mcv, Mean Corpuscular Volume; Mchc, Mean Corpuscular Hemoglobin Concentration; Rdw, Relative Distribution Width.

function, which may have important clinical consequences if confirmed in human CKD. Induction of improvement in CKD BMC function by HMGCR inhibition within 2 hours is remarkable but seems consistent with previous reports showing that short-term statin incubation $(<10$ minutes) induces a rapid elevation of $\mathrm{NO}$ production in endothelial cells [35] and rapid (<30 minutes) induction of Akt-mediated phosphorylation of endothelial NO synthase leading to NO production [36].

Filtration fraction was increased in CKD + DMEM $\mathrm{BMC}$ recipients versus healthy $\mathrm{BMC}$ recipients $(P<0.05)$, indicating a less well preserved glomerular structure. Mean arterial pressure was $20 \mathrm{mmHg}$ lower in rats that received $\mathrm{CKD}+$ pravastatin $\mathrm{CKD}$ BMCs or healthy + DMEM BMCs compared with recipients that received CKD + DMEM BMCs, and healthy + DMEM BMC, healthy + pravastatin BMC and CKD + pravastatin BMC recipients tended to have a higher natriuresis per 24 hours versus CKD + DMEM BMC recipients. Blood pressure lowering of $20 \mathrm{mmHg}$ has major renal and cardiovascular implications such as decreased risk of stroke [37], myocardial infarction, cardiac failure [38] and peripheral arterial disease and an increased life expectancy [39]. Consistently, we observed significantly less glomerulosclerosis, tubular inflammation, atrophy and fibrosis in remnant kidneys of rats that received $\mathrm{CKD}+$ pravastatin BMCs compared with CKD + DMEM BMC recipients. Cardiac fibrosis tended to be increased in CKD + DMEM BMC recipients compared with $\mathrm{CKD}+$ pravastatin BMC recipients. $E x$ vivo pravastatin treatment did not further improve renal function or structure or decrease cardiac fibrosis in healthy + pravastatin BMC recipients compared with 


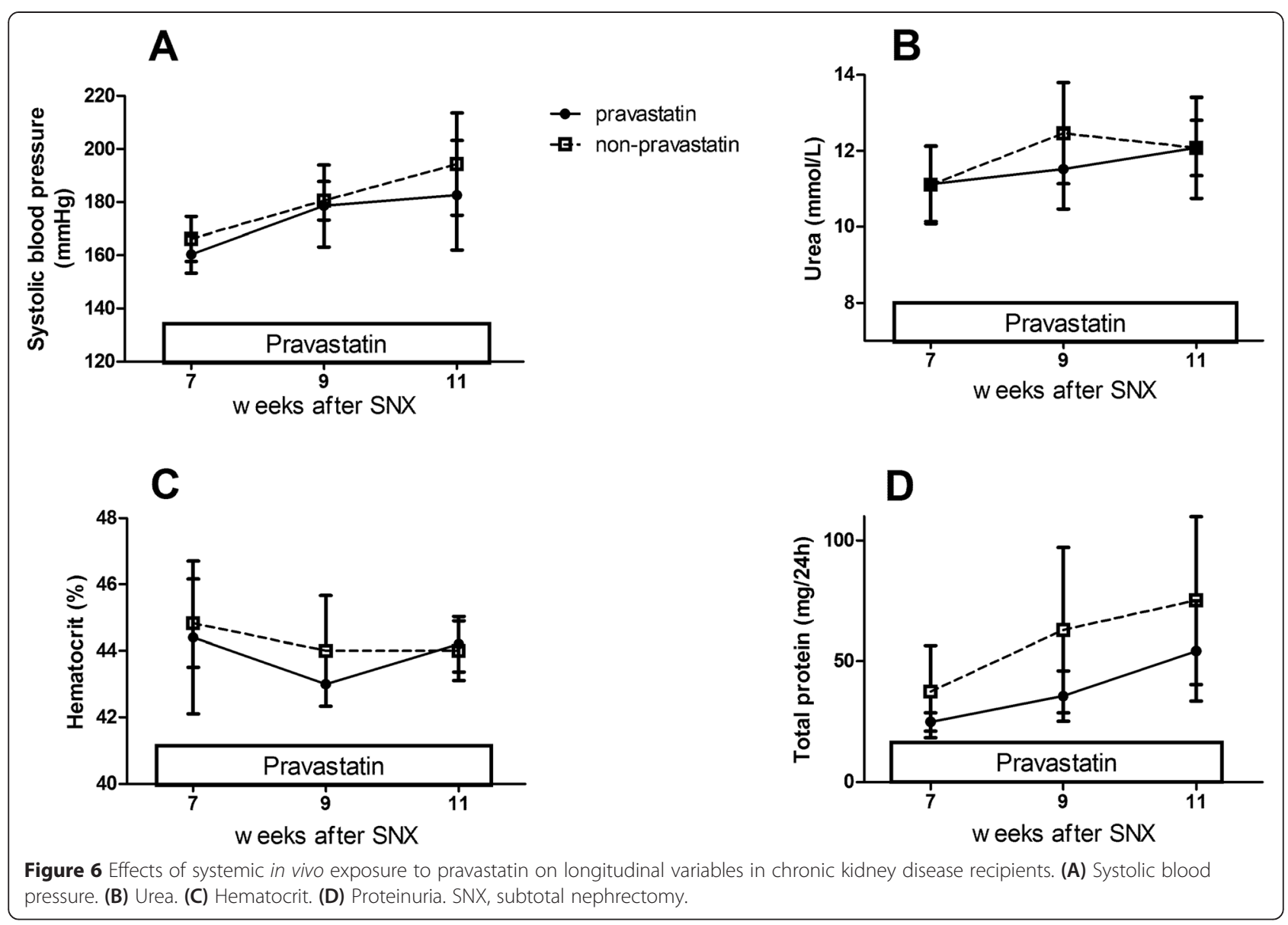

Figure 6 Effects of systemic in vivo exposure to pravastatin on longitudinal variables in chronic kidney disease recipients. (A) Systolic blood pressure. (B) Urea. (C) Hematocrit. (D) Proteinuria. SNX, subtotal nephrectomy.

Table 7 Terminal measurements after systemic in vivo pravastatin treatment

\begin{tabular}{lll}
\hline Week $\mathbf{1 2}$ & CKD $(\boldsymbol{n}=\mathbf{6})$ & $\begin{array}{l}\text { CKD + pravastatin } \\
(\boldsymbol{n}=\mathbf{5})\end{array}$ \\
\hline Body weight $(\mathrm{g})$ & $357 \pm 24$ & $369 \pm 16$ \\
Heart weight $(\mathrm{g} / 100 \mathrm{~g} \mathrm{BW})$ & $0.45 \pm 0.02$ & $0.42 \pm 0.03^{*}$ \\
Kidney weight $(\mathrm{g} / 100 \mathrm{~g} \mathrm{BW})$ & $0.57 \pm 0.02$ & $0.57 \pm 0.04$ \\
MAP $(\mathrm{mmHg})$ & $168 \pm 19$ & $164 \pm 19$ \\
GFR $(\mu \mathrm{l} / \mathrm{minute} / 100 \mathrm{~g})$ & $340 \pm 60$ & $332 \pm 41$ \\
ERPF $(\mu \mathrm{l} / \mathrm{minute} / 100 \mathrm{~g})$ & $1335 \pm 291$ & $1221 \pm 189$ \\
Hematocrit & $0.41 \pm 0.02$ & $0.40 \pm 0.02$ \\
FF $(\%)$ & $28 \pm 3$ & $26 \pm 2$ \\
Cholesterol (mmol/l) & $2.89 \pm 0.53$ & $2.73 \pm 0.46$ \\
Triglycerides (mmol/l) & $1.42 \pm 0.38$ & $0.70 \pm 0.37^{*}$ \\
Fold change hepatic & $1.000 \pm 0.56$ & $1.584 \pm 0.65$ \\
HMGCR mRNA expression & &
\end{tabular}

Data presented as mean \pm standard deviation. BW, body weight; $C K D$, chronic kidney disease; ERPF, effective renal plasma flow; FF, filtration fraction; GFR, glomerular filtration rate; HMGCR, 3-hydroxy-3-methyl-glutaryl-CoA reductase; MAP, mean arterial pressure. ${ }^{*} P<0.05$ compared with CKD. healthy + DMEM BMC recipients, whereas in CKD + pravastatin BMC recipients cardiac fibrosis was significantly decreased compared with CKD + DMEM BMC recipients, indicating that pravastatin specifically corrected CKD BMC function. We have not compared different statins in our experimental setup, and therefore our study does not allow conclusions as to whether this phenomenon is a specific effect of pravastatin or a generic statin effect.

Table 8 Longitudinal, terminal and histological measurements after in vivo pravastatin treatment

\begin{tabular}{lll}
\hline & CKD $(\boldsymbol{n}=\mathbf{6})$ & CKD + pravastatin $(\boldsymbol{n}=\mathbf{5})$ \\
\hline Focal glomerulosclerosis (\%) & & \\
$\quad$ Normal & $32.9 \pm 7.6$ & $23.4 \pm 13.1$ \\
$\quad$ Partial & $48.1 \pm 10.6$ & $62.7 \pm 10.4$ \\
$\quad$ Total & $19.0 \pm 6.7$ & $14.0 \pm 15.8$ \\
Tubulo-interstitial damage & & \\
$\quad$ Fibrosis & $0.78 \pm 0.31$ & $0.85 \pm 0.14$ \\
Inflammation & $1.72 \pm 0.54$ & $1.66 \pm 0.22$ \\
Atrophy & $1.09 \pm 0.65$ & $0.56 \pm 0.09$
\end{tabular}

Data presented as mean \pm standard deviation. CKD, chronic kidney disease. 
Interestingly, 6 weeks of systemic in vivo treatment with pravastatin did not influence CKD progression or renal fibrosis in our model of established CKD. Although cholesterol-lowering effects of statins do not occur in rodents, pleiotropic effects have been reported [40] such as reduced inflammation and oxidative stress, enhanced endothelial function and increased mobilization and function of EPCs. Some older studies showed beneficial effects of statins on renal function and morphology in experimental CKD, although others reported harmful effects such as induction of renal fibrosis [41,42]. Recently, Geng and colleagues performed a meta-analysis on the effect of statins on renal function (estimated GFR and proteinuria) in patients with CKD. The analysis showed that the beneficial effect of statins on renal function may be dose and time dependent and that statins are well tolerated in patients with National Kidney Foundation Kidney Disease Outcomes Quality Initiative stages 1 to 3. However, the effect of statins on renal function in National Kidney Foundation Kidney Disease Outcomes Quality Initiative stages 4 and 5 remains controversial [43]. The lack of effect of statin treatment in our in vivo study cannot be explained by insufficient dosing of pravastatin. Similar statin doses have previously been shown to increase EPC mobilization in mice [44]. Furthermore, we observed a significant decrease in triglycerides and an increase in HMGCR mRNA expression after systemic pravastatin treatment, which indicates that the dose was sufficient to affect the mevalonate pathway, and is in agreement with Zager and colleagues [45].

\section{Conclusions}

Short-term pretreatment of CKD BMCs with pravastatin reversed CKD BMC dysfunction and improved the cells' therapeutic efficacy in vivo. Our data suggest that this is due to an improvement in their paracrine profile. In contrast, systemic in vivo pravastatin treatment did not attenuate the progressive course of CKD. Our findings have relevance for potential clinical application of BMC therapy in patients with CKD as clinical application would involve autologous - and thus CKD - BMCs to avoid immunological reactions. If confirmed for human CKD BMCs, our findings will provide a basis for development of clinical trials and application of autologous $\mathrm{BMC}$-based therapies in human CKD.

\footnotetext{
Abbreviations

BM: bone marrow; BMC: bone marrow cell; CKD: chronic kidney disease; CXCL: chemokine (C-X-C motif) ligand; DMEM: Dulbecco's modified Eagle medium; eGFP: enhanced green fluorescent protein; EPC: endothelial progenitor cell; ERPF: effective renal plasma flow; GFR: glomerular filtration rate; HMGCR: 3-hydroxy-3-methyl-glutaryl Coenzyme A reductase; MSC: mesenchymal stem cell; NO: nitric oxide; SDF1a: stromal derived factor 1 alpha; TUNEL: terminal deoxynucleotidyl transferase dUTP nick end labeling.
}

\section{Competing interests}

The authors declare that they have no competing interests.

\section{Authors' contributions}

AvK designed and carried out the in vitro and in vivo experiments, performed the data analysis and interpretation, and wrote the manuscript. DAP participated in the in vivo experiments. NRO participated in the in vitro experiments and performed the flow cytometer and quantitative real-time PCR experiments. HG designed and carried out the flow cytometer analysis. $\mathrm{RHG}, J O F, J A J$ and MCV participated in the conception and design, data analysis, and interpretation of the experiments. All authors read and approved the final manuscript.

\section{Acknowledgements}

The authors thank Krista den Ouden, Adele Dijk, Nel Willekes, Maaike Meerlo, and Paula Martens for their expert technical assistance.

This study was financially supported by the Dutch Kidney Foundation, grant C06.2174, and ZonMw Translational Adult Stem Cell research grant

116001026. M.C.V. is supported by the Netherlands Organisation for Scientific Research (NWO) Vidi-grant 016.096.359. R.H.G. acknowledges support from the EU FP7/2009 Consortium "SYSCILIA" (n²41955) and the Dutch Kidney Foundation "Kouncil" Consortium Grant CP11.

\section{Author details}

'Department of Nephrology \& Hypertension, University Medical Center Utrecht, F03.223, Heidelberglaan 100, Utrecht 3584 CX, The Netherlands. ${ }^{2}$ Department of Metabolic Health Research, The Netherlands Organization for Applied Scientific Research (TNO), Zernikedreef 9, 2333 CK, Leiden, The Netherlands.

Received: 31 October 2014 Revised: 18 February 2015

Accepted: 24 March 2015 Published online: 15 April 2015

\section{References}

1. van Koppen A, Joles JA, Bongartz LG, van den Brandt J, Reichardt HM, Goldschmeding R, et al. Healthy Bone Marrow Cells Reduce Progression of Kidney Failure Better Than CKD Bone Marrow Cells in Rats With Established Chronic Kidney Disease. Cell Transplant. 2012;21:2299-312.

2. Landmesser U, Engberding N, Bahlmann FH, Schaefer A, Wiencke A, Heineke A, et al. Statin-induced improvement of endothelial progenitor cell mobilization, myocardial neovascularization, left ventricular function, and survival after experimental myocardial infarction requires endothelial nitric oxide synthase. Circulation. 2004;110:1933-9.

3. Li TS, Takahashi M, Suzuki R, Kobayashi T, Ito H, Mikamo A, et al. Pravastatin improves remodeling and cardiac function after myocardial infarction by an antiinflammatory mechanism rather than by the induction of angiogenesis. Ann Thorac Surg. 2006;81:2217-25.

4. Xu H, Yang YJ, Qian HY, Tang YD, Wang H, Zhang Q. Rosuvastatin treatment activates JAK-STAT pathway and increases efficacy of allogeneic mesenchymal stem cell transplantation in infarcted hearts. Circ J. 2011;75:1476-85.

5. Lavi R, Zhu XY, Chade AR, Lin J, Lerman A, Lerman LO. Simvastatin decreases endothelial progenitor cell apoptosis in the kidney of hypertensive hypercholesterolemic pigs. Arterioscler Thromb Vasc Biol. 2010;30:976-83.

6. Lu L, Zhou JZ, Wang L, Zhang TX. Effects of Xuezhikang and pravastatin on circulating endothelial progenitor cells in patients with essential hypertension. Chin J Integr Med. 2009;15:266-71.

7. Liu Y, Wei J, Hu S, Hu L. Beneficial effects of statins on endothelial progenitor cells. Am J Med Sci. 2012;344:220-6.

8. Yang YJ, Qian HY, Huang J, Li JJ, Gao RL, Dou KF, et al. Combined therapy with simvastatin and bone marrow-derived mesenchymal stem cells increases benefits in infarcted swine hearts. Arterioscler Thromb Vasc Biol. 2009;29:2076-82

9. Song L, Yang YJ, Dong QT, Qian HY, Gao RL, Qiao SB, et al. Atorvastatin enhance efficacy of mesenchymal stem cells treatment for swine myocardial infarction via activation of nitric oxide synthase. PLoS One 2013;8:e65702.

10. Assmus B, Urbich C, Aicher A, Hofmann WK, Haendeler J, Rossig L, et al. HMG-CoA reductase inhibitors reduce senescence and increase proliferation of endothelial progenitor cells via regulation of cell cycle regulatory genes. Circ Res. 2003;92:1049-55. 
11. Emanueli C, Monopoli A, Kraenkel N, Meloni M, Gadau S, Campesi I, et al. Nitropravastatin stimulates reparative neovascularisation and improves recovery from limb Ischaemia in type-1 diabetic mice. Br J Pharmacol. 2007;150:873-82

12. Mangialardi G, Monopoli A, Ongini E, Spinetti G, Fortunato O, Emanueli C, et al. Nitric oxide-donating statin improves multiple functions of circulating angiogenic cells. Br J Pharmacol. 2011;164:570-83.

13. Park KW, Hwang KK, Cho HJ, Hur J, Yang HM, Yoon CH, et al. Simvastatin enhances endothelial differentiation of peripheral blood mononuclear cells in hypercholesterolemic patients and induces pro-angiogenic cytokine IL-8 secretion from monocytes. Clin Chim Acta. 2008;388:156-66.

14. Pirro M, Schillaci G, Romagno PF, Mannarino MR, Bagaglia F, Razzi R, et al. Influence of short-term rosuvastatin therapy on endothelial progenitor cells and endothelial function. J Cardiovasc Pharmacol Ther. 2009;14:14-21.

15. Rupp S, Badorff C, Koyanagi M, Urbich C, Fichtlscherer S, Aicher A, et al. Statin therapy in patients with coronary artery disease improves the impaired endothelial progenitor cell differentiation into cardiomyogenic cells. Basic Res Cardiol. 2004;99:61-8.

16. Satoh M, Minami Y, Takahashi Y, Tabuchi T, Itoh T, Nakamura M. Effect of intensive lipid-lowering therapy on telomere erosion in endothelial progenitor cells obtained from patients with coronary artery disease. Clin SCi (Lond). 2009;116:827-35.

17. Yu J, Li M, Qu Z, Yan D, Li D, Ruan Q. SDF-1/CXCR4-mediated migration of transplanted bone marrow stromal cells toward areas of heart myocardial infarction through activation of PI3K/Akt. J Cardiovasc Pharmacol. 2010;55:496-505.

18. Vandesompele, Genorm. 2013 http://medgen.ugent.be/ jvdesomp/genorm/ last accessed date 22-4-2015.

19. van Koppen A, Joles JA, van Balkom BW, Lim SK, de Kleijn D, Giles RH, et al Human embryonic mesenchymal stem cell-derived conditioned medium rescues kidney function in rats with established chronic kidney disease. PLoS One. 2012;7:e38746.

20. Koeners MP, Racasan S, Koomans HA, Joles JA, Braam B. Nitric oxide, superoxide and renal blood flow autoregulation in SHR after perinatal L-arginine and antioxidants. Acta Physiol (Oxf). 2007;190:329-38.

21. Attia DM, Verhagen AM, Stroes ES, van Faassen EE, Grone HJ, De Kimpe SJ, et al. Vitamin E alleviates renal injury, but not hypertension, during chronic nitric oxide synthase inhibition in rats. J Am Soc Nephrol. 2001;12:2585-93.

22. Bongartz LG, Braam B, Verhaar MC, Cramer MJ, Goldschmeding R, Gaillard $C A$, et al. The nitric oxide donor molsidomine rescues cardiac function in rats with chronic kidney disease and cardiac dysfunction. Am J Physiol Heart Circ Physiol. 2010;299:H2037-45.

23. van Koppen A, Joles JA, Verhaar MC. Bone marrow cell therapy in hypertensive kidney disease: contribution to cardiac fibrosis? J Hypertens. 2013;31:1052-4

24. Doorn J, Moll G, Le Blanc K, van Blitterswijk C, de Boer J. Therapeutic applications of mesenchymal stromal cells: paracrine effects and potential improvements. Tissue Eng Part B Rev. 2012;18:101-15.

25. Chandrasekar B, Melby PC, Sarau HM, Raveendran M, Perla RP, Marelli-Berg FM, et al. Chemokine-cytokine cross-talk. The ELR+ CXC chemokine LIX (CXCL5) amplifies a proinflammatory cytokine response via a phosphatidylinositol 3-kinase-NF-kappa B pathway. J Biol Chem. 2003;278:4675-86.

26. Zineh I, Luo X, Welder GJ, Debella AE, Wessel TR, Arant CB, et al. Modulatory effects of atorvastatin on endothelial cell-derived chemokines, cytokines, and angiogenic factors. Pharmacotherapy. 2006;26:333-40.

27. Nenseter MS, Aukrust P, Ose L, Holven KB. Low level of inflammatory marker in hyperhomocysteinemic patients on statin therapy. Scand J Clin Lab Invest. 2013;74:1-7.

28. Yuen DA, Connelly KA, Zhang Y, Advani SL, Thai K, Kabir G, et al. Early outgrowth cells release soluble endocrine antifibrotic factors that reduce progressive organ fibrosis. Stem Cells. 2013;31:2408-19.

29. Ziegelhoeffer T, Fernandez B, Kostin S, Heil M, Voswinckel R, Helisch A, et al. Bone marrow-derived cells do not incorporate into the adult growing vasculature. Circ Res. 2004;94:230-8.

30. Jie KE, Zaikova MA, Bergevoet MW, Westerweel PE, Rastmanesh M, Blankestijn PJ, et al. Progenitor cells and vascular function are impaired in patients with chronic kidney disease. Nephrol Dial Transplant. 2010;25:1875-82.

31. Westerweel PE, Hoefer IE, Blankestijn PJ, de Bree P, Groeneveld D, van Oostrom $\mathrm{O}$, et al. End-stage renal disease causes an imbalance between endothelial and smooth muscle progenitor cells. Am J Physiol Renal Physiol. 2007;292:F1132-40.
32. Chan CT, Li SH, Verma S. Nocturnal hemodialysis is associated with restoration of impaired endothelial progenitor cell biology in end-stage renal disease. Am J Physiol Renal Physiol. 2005;289:F679-84

33. de Groot K, Bahlmann FH, Sowa J, Koenig J, Menne J, Haller H, et al. Uremia causes endothelial progenitor cell deficiency. Kidney Int. 2004;66:641-6.

34. Choi JH, Kim KL, Huh W, Kim B, Byun J, Suh W, et al. Decreased number and impaired angiogenic function of endothelial progenitor cells in patients with chronic renal failure. Arterioscler Thromb Vasc Biol. 2004;24:1246-52.

35. Kaesemeyer WH, Caldwell RB, Huang J, Caldwell RW. Pravastatin sodium activates endothelial nitric oxide synthase independent of its cholesterol-lowering actions. J Am Coll Cardiol. 1999;33:234-41.

36. Kureishi Y, Luo Z, Shiojima I, Bialik A, Fulton D, Lefer DJ, et al. The HMG-CoA reductase inhibitor simvastatin activates the protein kinase Akt and promotes angiogenesis in normocholesterolemic animals. Nat Med. 2000;6:1004-10.

37. Shimbo D, Levitan EB, Booth III JN, Calhoun DA, Judd SE, Lackland DT, et al. The contributions of unhealthy lifestyle factors to apparent resistant hypertension: findings from the Reasons for Geographic And Racial Differences in Stroke (REGARDS) study. J Hypertens. 2013;31:370-6.

38. Barnett CF, De Marco T. Pulmonary hypertension associated with left-sided heart disease. Heart Fail Clin. 2012;8:447-59.

39. Mahmoodi BK, Matsushita K, Woodward M, Blankestijn PJ, Cirillo M, Ohkubo $\mathrm{T}$, et al. Associations of kidney disease measures with mortality and end-stage renal disease in individuals with and without hypertension: a meta-analysis. Lancet. 2012;380:1649-61.

40. Nam HK, Lee SJ, Kim MH, Rho JH, Son YK, Lee SM, et al. Rosuvastatin Attenuates Inflammation, Apoptosis and Fibrosis in a Rat Model of Cyclosporine-Induced Nephropathy. Am J Nephrol. 2012;37:7-15.

41. Kassimatis TI, Konstantinopoulos PA. The role of statins in chronic kidney disease (CKD): friend or foe? Pharmacol Ther. 2009;122:312-23.

42. Kalaitzidis RG, Elisaf MS. The role of statins in chronic kidney disease. Am J Nephrol. 2011;34:195-202.

43. Geng Q, Ren J, Song J, Li S, Chen H. Meta-analysis of the effect of statins on renal function. Am J Cardiol. 2014;114:562-70.

44. Dimmeler S, Aicher A, Vasa M, Mildner-Rihm C, Adler K, Tiemann M, et al. HMG-CoA reductase inhibitors (statins) increase endothelial progenitor cells via the PI 3-kinase/Akt pathway. J Clin Invest. 2001;108:391-7.

45. Zager RA, Johnson AC, Hanson SY. Sepsis syndrome stimulates proximal tubule cholesterol synthesis and suppresses the SR-B1 cholesterol transporter. Kidney Int. 2003;63:123-33.

\section{Submit your next manuscript to BioMed Central and take full advantage of:}

- Convenient online submission

- Thorough peer review

- No space constraints or color figure charges

- Immediate publication on acceptance

- Inclusion in PubMed, CAS, Scopus and Google Scholar

- Research which is freely available for redistribution 